\title{
EFFECTS OF MICRO RESISTANCE SPOT WELDING PARAMETERS ON THE QUALITY OF WELD JOINTS ON ALUMINUM THIN PLATE AA 1100
}

\author{
Ario Sunar Baskoro $^{1 *}$, Hakam Muzakki ${ }^{1}$, Gandjar Kiswanto ${ }^{1}$, Winarto ${ }^{2}$ \\ ${ }^{1}$ Department of Mechanical Engineering, Faculty of Engineering, Universitas Indonesia, Kampus UI \\ Depok, Depok 16424, Indonesia \\ ${ }^{2}$ Department of Metallurgy and Material Engineering, Faculty of Engineering, Universitas \\ Indonesia, Kampus UI Depok, Depok 16424 Indonesia
}

(Received: January 2017 / Revised: June 2017 / Accepted: November 2017)

\begin{abstract}
Resistance spot welding (RSW) is widely used in industries such as the aerospace, automotive, and electrical application industries. RSW is very useful for joining aluminum and its welding parameters lead to good quality joints. This research studied the influence of the welding parameters, such as welding current, welding time, and the electrode force, of micro resistance spot welding (MRSW) on the mechanical properties and fracture of a nugget of aluminum alloy (AA) 1100. AA 1100 plate with a thickness of $0.4 \mathrm{~mm}$ was used in this experiment. An alternating current (AC) RSW machine and electrode were used in this study. The welding parameters used in this study are welding current, welding time, and electrode force. Holding time is assumed to be constant. The welding time values of $6 \mathrm{CT}, 8 \mathrm{CT}$, and $10 \mathrm{CT}$ were combined with a welding current of $8 \mathrm{kV}$, and electrode forces of $32 \mathrm{~kg}, 42 \mathrm{~kg}$, and $52 \mathrm{~kg}$. The results showed that by increasing the electrode force, the load rate decreases, and the elongation distance tends to decrease, except for the electrode force of $52 \mathrm{Kg}$. The effect of the electrode force on the diameter and thickness of the weld nugget was not significant.
\end{abstract}

Keywords: $\quad$ Electrode force; Micro resistance spot welding (MRSW); Weld joints; Welding current; Welding time

\section{INTRODUCTION}

Resistance spot welding (RSW) is widely used in industries such as the aerospace, automotive, and electrical industries (Bi et al., 2016). RSW is very useful for joining aluminum and its welding parameters lead directly to good quality joints (Baskoro et al., 2016), and good quality weld nuggets. However, welding technology has some problems, especially with regard to optimizing the welding parameters for joining thin aluminum (Baskoro et al., 2016). Research and studies have been conducted to improve the technology. Some researchers have studied RSW parameters. Hernandez et al. (2010) studied the hardness of the base metal and the heataffected zone resulting from RSW. They show that effect of the tempering is a smaller area for the heat-affected zone and hence caused a softer region. Pal and Bhowmick (2012) investigated the characteristics and high-cycle fatigue behavior of a DP 780 steel sheet welded by RSW. The fracture toughness of the molten zone of advanced high-strength steel was joined by RSW in a study by Krajcarz et al. (2013).

The fracture toughness at crash initiation is independent of the nugget's diameter and is based

\footnotetext{
*Corresponding author's email: ario@eng.ui.ac.id, Tel. +62-21-7270032, Fax. +62-21-7270033

Permalink/DOI: https://doi.org/10.14716/ijtech.v8i7.705
} 
on the metal's properties, and the crack-extension resistance depends on the nugget's diameter and is based on the material's properties. The current and welding time of RSW on austenitic stainless-steel sheets of grade AISI 316L have been optimized by Kianersi et al. (2014).

Changes in the microstructure of the weld nugget was effected by a fast cooling rate (Kianersi et al., 2014). The effect of the welding time and welding current used in RSW on the tensile shear strength and nugget thickness was also studied by Baskoro et al. (2015). Zohoori-Shoar et al. (2017) evaluated the RSW process to produce ultrafine grained/nanostructured Al 6061 alloy joints. The electrode force and welding time were kept constant. This study evaluated the influence of electrode force and welding time on tensile strength and microstructure for an AA 1100 sheet with a thickness of less than $1 \mathrm{~mm}$.

Micro resistance spot welding is RSW that is used to join plate of less than $1 \mathrm{~mm}$ thickness (Baskoro et al., 2015; Papaefthymioua et al., 2015, Baskoro et al., 2016). There is still only a limited number of investigations on the tensile strength and macrostructure conditions in the weld nuggets that have been created using various welding times and electrode forces through MRSW. The welding time and electrode force are factors impacting the density of weld nugget. The electrode-force parameter also affects whether there are holes or cracks in the weld nugget, particularly in thin plate. Aluminum alloy (AA) 1100 is a material that is not easy to be weld. This study investigates, through macrostructure analysis, how the thickness and weld-nugget diameter are affected by MRSW. This research also studies the tensile strength and analyzes the macrostructure of the weld nugget, which is influenced by the welding time and electrode force.

\section{METHODOLOGY}

\subsection{Material}

AA 1100 sheet has mechanical properties and a chemical composition. The mechanical properties represent the performance of the base metal, and the chemical composition of the parent metal is important information for analyzing microstructure. The mechanical properties and chemical composition of AA 1100 are shown in Table 1 and Table 2, respectively.

Table 1 Mechanical properties

\begin{tabular}{llr}
\hline \multicolumn{1}{c}{ Properties } & Unit & \multicolumn{1}{c}{ Value } \\
\hline Hardness, Brinell & $\mathrm{HB}$ & 23 \\
Ultimate Tensile Strength & $\mathrm{MPa}$ & 89.6 \\
Tensile Yield Strength & $\mathrm{MPa}$ & 34.5 \\
Electrical Resistivity & $\mathrm{ohm}-\mathrm{cm}$ & 0.00000299 \\
Specific Heat Capacity & $\mathrm{J} / \mathrm{g}-{ }^{\circ} \mathrm{C}$ & 0.904 \\
Thermal Conductivity & $\mathrm{W} / \mathrm{m}-\mathrm{K}$ & 222 \\
Melting Point & ${ }^{\circ} \mathrm{C}$ & $643-657.2$ \\
Solidus & ${ }^{\circ} \mathrm{C}$ & 643 \\
Liquidus & ${ }^{\circ} \mathrm{C}$ & 657.2 \\
\hline
\end{tabular}

Table 2 Chemical composition

\begin{tabular}{cccccc}
\hline $\mathrm{Al}$ & $\mathrm{Be}$ & $\mathrm{Cu}$ & $\mathrm{Mn}$ & $\mathrm{Si}+\mathrm{Fe}$ & $\mathrm{Zn}$ \\
\hline $99.0 \%$ & $0.0008 \%$ & $0.050-0.20 \%$ & $0.050 \%$ & $0.95 \%$ & $0.10 \%$ \\
\hline
\end{tabular}

AA 1100 with a thickness of $0.4 \mathrm{~mm}$ was cut into pieces of size $19 \mathrm{~mm} \times 76 \mathrm{~mm}$, according to the American Welding Society (AWS) guidelines (Razmpoosh et al., 2015). A specimen of the 
material used is shown Figure 1. The specimens were cleaned using acetone (Aqua Thinner) (Papaefthymioua et al., 2015).

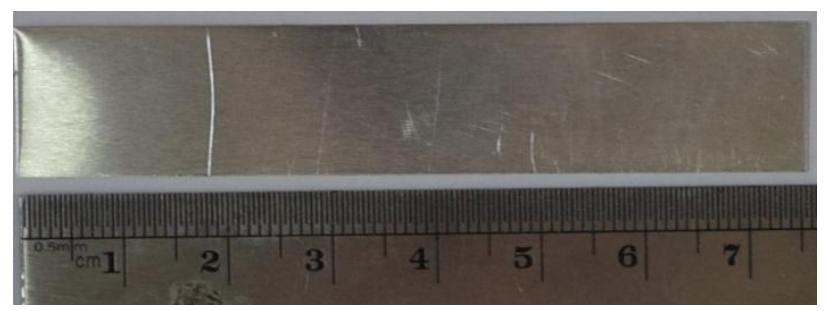

Figure 1 Material of AA 1100

\subsection{Welding Process}

The electrical source of the RSW machine uses AC, single phase, $220 \mathrm{~V}$, without a cooling system. The RSW machine used in this study is shown in Figure 2.

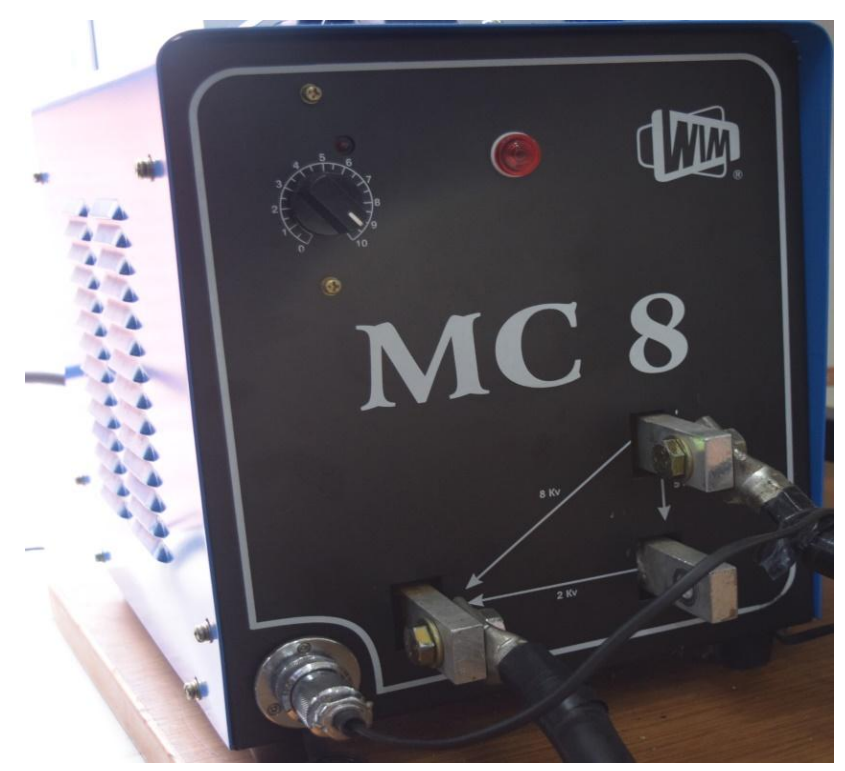

Figure 2 Welding machine

The welding parameters of welding time and electrode force were combined. The welding current of $8 \mathrm{kVA}$ and the holding time of $10 \mathrm{sec}$ were kept constant. The welding time values of $6 \mathrm{CT}, 8 \mathrm{CT}$, and $10 \mathrm{CT}$ were combined with electrode forces of $32 \mathrm{~kg}, 42 \mathrm{~kg}$, and $52 \mathrm{~kg}$. A combination of welding parameters was used for the specimen code, as illustrated in Table 3.

Table 3 Specimen code representation

\begin{tabular}{lccc}
\hline Specimen Code & $\begin{array}{c}\text { Welding Current } \\
(\mathrm{kVA})\end{array}$ & $\begin{array}{c}\text { Welding Time } \\
(\text { Hernandez et al. })\end{array}$ & $\begin{array}{c}\text { Electrode Force } \\
(\mathrm{Kg})\end{array}$ \\
\hline C8T6F32 & 8 & 6 & 32 \\
C8T8F42 & 8 & 8 & 42 \\
C8T10F52 & 8 & 10 & 52 \\
\hline
\end{tabular}

Each welding combination was used to join four specimens: three specimens for tensile testing, and one for micro and macro analysis. 


\subsection{Tensile Shear Test}

An RTF-2350 tensile test machine was used in this study, with a specification of $50 \mathrm{kN}$ maximum load, $798 \mathrm{~mm}$ of effective stroke, and $0.0005-1,000 \mathrm{~mm} / \mathrm{min}$ of cross head speed. A welded specimen is shown in Figure 3.

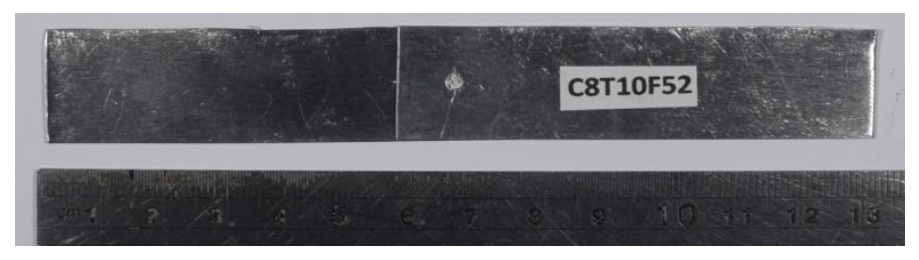

Figure 3 Welded specimen

\subsection{Macrostructure Specimen Preparation}

The welded specimens were prepared for macro and micro analysis. In the macrostructure analysis, the weld-nugget diameter was measured, and the microstructure analysis studied the composition of both metal parents. The welded specimens were cut and put into a resin mold. An abrasive paper was used to cut the center position for the electrode imprint. The crosssection's surface was polished and etched (Xu et al., 2017). A specimen that is ready to be measured and analyzed is shown in Figure 4.

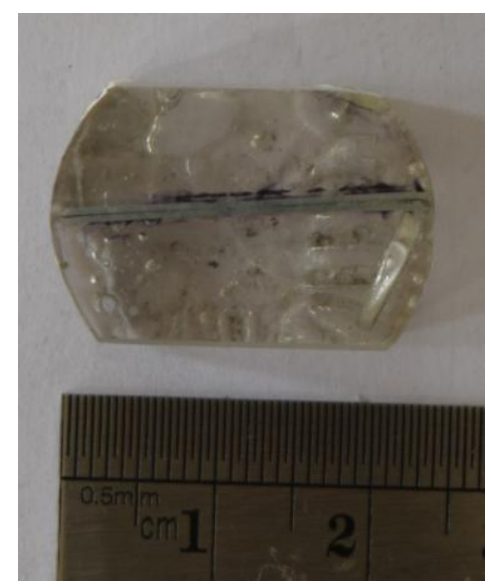

Figure 4 Specimen for micro and macro analysis

\subsection{Macrostructure Analysis}

The microstructure analysis was performed using a digital microscope. The distance of the mixed zone is represented by the weld-nugget diameter. The result of the measurement is displayed in Figure 5.

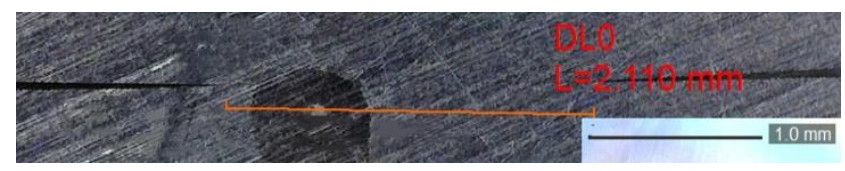

Figure 5 Result of measurement

\section{RESULTS AND DISCUSSION}

\subsection{Tensile Shear Test}

The results of tensile shear test for the three specimens that were welded using an $8 \mathrm{kVA}$ welding current, 6 CT welding time, and $32 \mathrm{~kg}, 42 \mathrm{~kg}$, and $52 \mathrm{~kg}$ electrode force are revealed in Figure 6. 


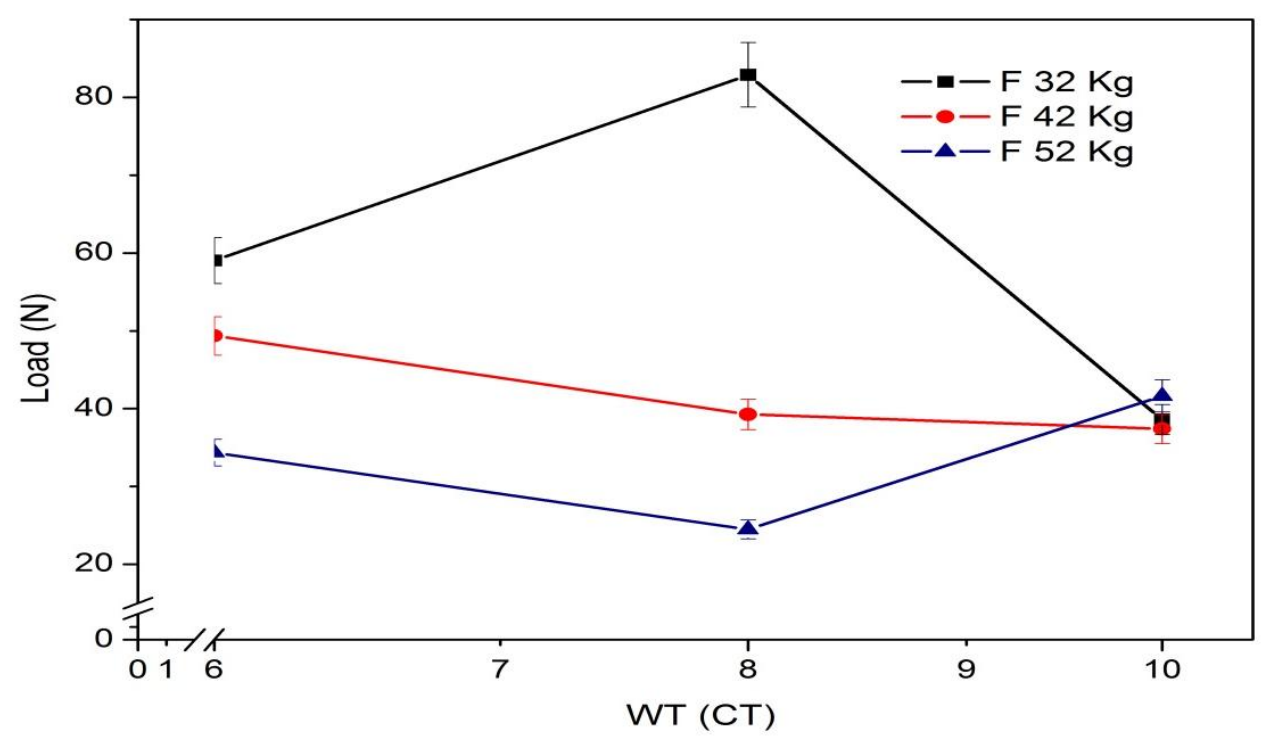

Figure 6 Load of each welding-parameter combination

Figure 6 shows that the load decreases when the electrode force increases. However, in the welding process using $8 \mathrm{kVA}$ welding current, $8 \mathrm{CT}$ welding time, and $32 \mathrm{~kg}$ electrode force, the load increased from $59 \mathrm{~N}$ to $82.9 \mathrm{~N}$. The load for specimen C8T10F35 increased to $41.6 \mathrm{~N}$. Figure 6 also reveals that the specimens with $82.9 \mathrm{~N}$ (C8T8F32) and $24.5 \mathrm{~N}$ (C8T8F52) have the highest and lowest loads, respectively.

The highest load value of three specimens is shown in the load-elongation graphic. This graph represents the maximum load and distance elongation of each welding-parameter combination. The load and elongation for an electrode force of $32 \mathrm{~kg}$ are shown in Figure 7.

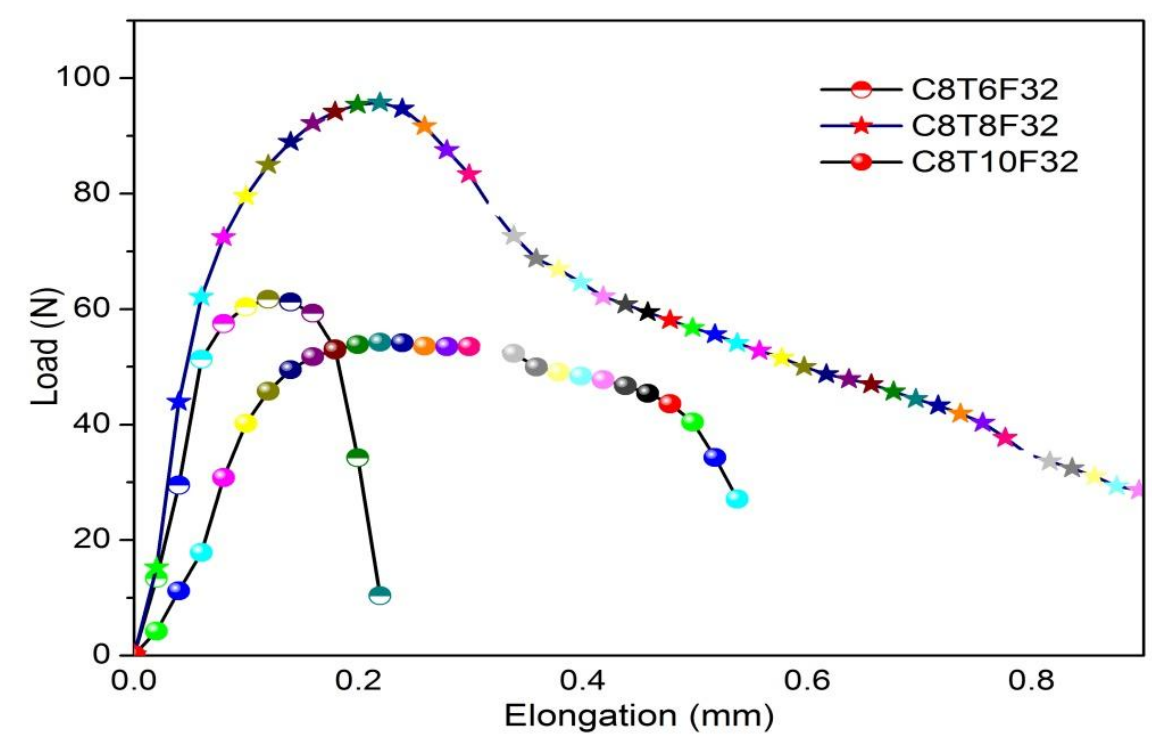

Figure 7 The load and elongation for an electrode force of $32 \mathrm{~kg}$

Figure 7 shows that the elongation of C8T8F32 is more than $0.8 \mathrm{~mm}$ and the maximum load is $95.77 \mathrm{~N}$. The elongation of C8T6F32 is the shortest, with a value near $0.2 \mathrm{~mm}$. The highest load values and elongation for an electrode force of $42 \mathrm{~kg}$ is represented in Figure 8. 


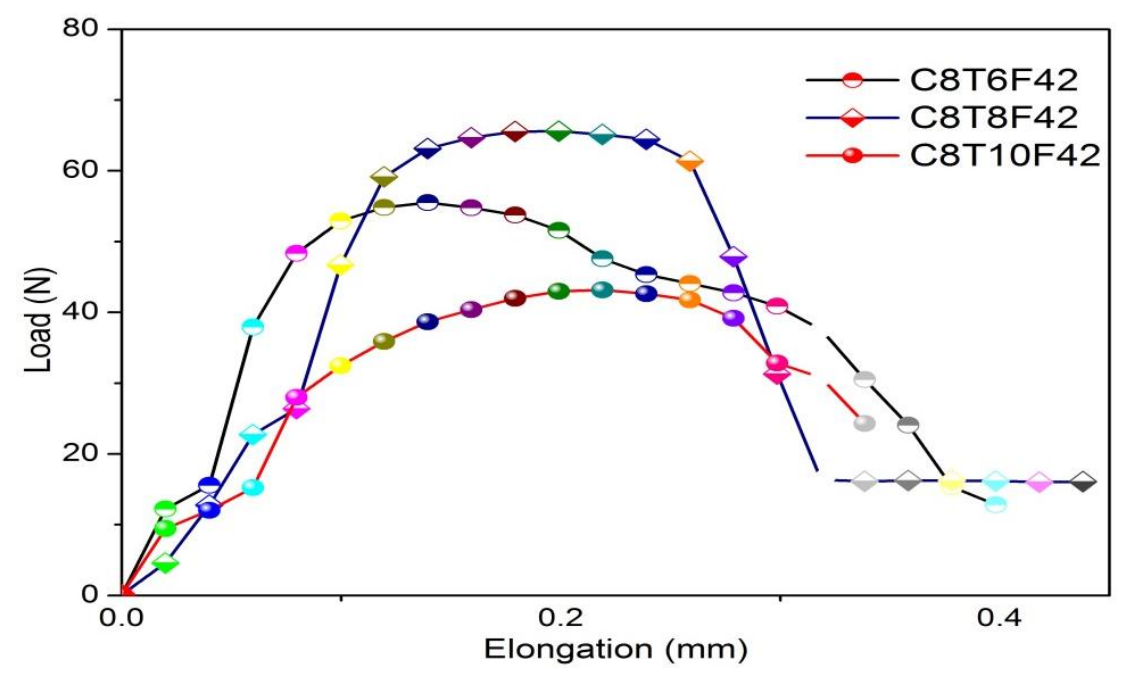

Figure 8 The load and elongation of an electrode force of $42 \mathrm{~kg}$

Figure 8 identifies the highest load of each of the three specimens welded by a welding current of $8 \mathrm{kVA}$, a welding time of $8 \mathrm{CT}$, and an electrode force of $42 \mathrm{~kg}$. The highest load value for C8T8F42 is $65.6 \mathrm{~N}$, and the highest load value for C8T6F42 is $55.5 \mathrm{~N}$. C8T10F42 has the lowest value of the specimens welded with $42 \mathrm{~kg}$ electrode force, for which the highest load value is $43.15 \mathrm{~N}$. The elongation distance for each welding-parameter combination is from 0.3 $\mathrm{mm}$ to $0.4 \mathrm{~mm}$.

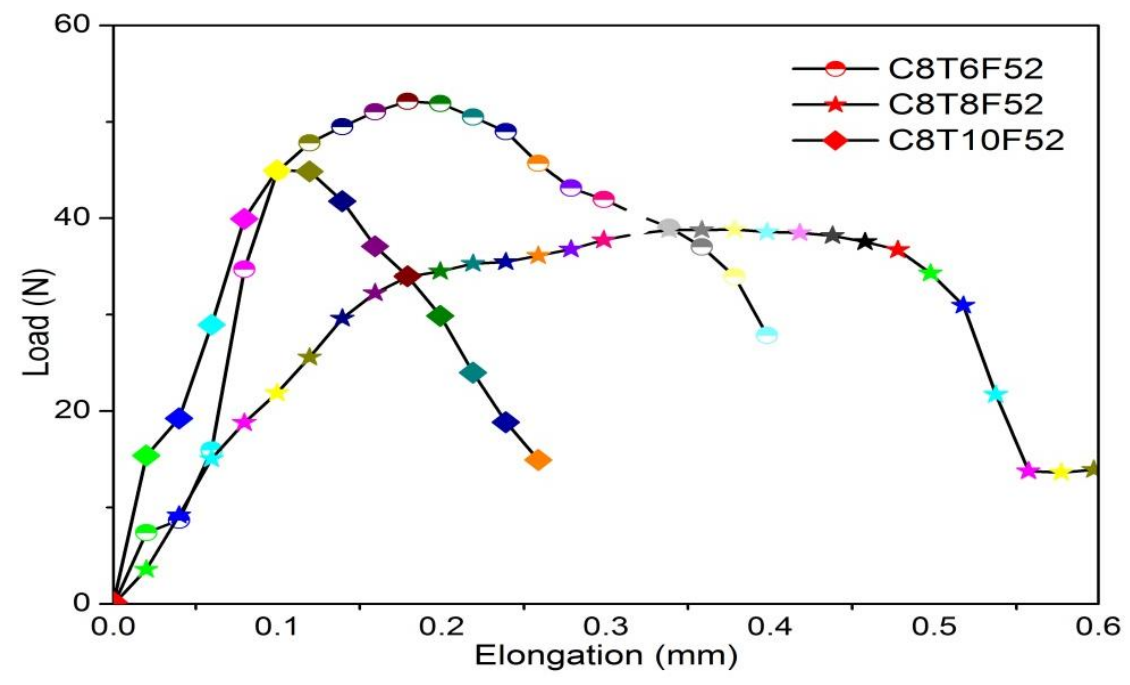

Figure 9 The load and elongation for an electrode force of $52 \mathrm{~kg}$

The tensile test results presented in Figure 9 identify that lowest load value for the weldingparameter combinations is $8.8 \mathrm{~N}$ for $\mathrm{C} 8 \mathrm{~T} 8 \mathrm{~F} 52$; however, the elongation distance for this specimen is the largest of the welding-parameter combinations. The elongation value for C8T8F52 is $0.56 \mathrm{~mm}$. The highest load value for an electrode force of $52 \mathrm{~kg}$ is for C8T6F52. It represents that the load value for this welding-parameter combination decreased. The shortest elongation for an electrode force of $52 \mathrm{~kg}$ is $0.256 \mathrm{~mm}$.

\subsection{Macrostructure Analysis}

The weld-nugget thickness and diameter were studied. The macrostructure specimens had to be prepared correctly to get precise results. A digital microscope was used to measure the nuggets' 
dimensions. The weld nugget developed by each welding-parameter combination was measured. The results of the microscope measurement are recapitulated and presented in the Table 4.

Table 4 Results of nugget dimension measurement

\begin{tabular}{clcc}
\hline Number & Specimen code & Diameter $(\mathrm{mm})$ & Thickness $(\mathrm{mm})$ \\
\hline 1 & C8T6F32 & 3.049 & 0.56 \\
2 & C8T8F32 & 2.781 & 0.77 \\
3 & C8T10F32 & 1.768 & 0.80 \\
4 & C8T6F42 & 1.778 & 0.79 \\
5 & C8T8F42 & 2.732 & 0.78 \\
6 & C8T10F42 & 3.342 & 0.74 \\
7 & C8T6F52 & 3.427 & 0.72 \\
8 & C8T8F52 & 2.317 & 0.72 \\
9 & C8T10F52 & 3.098 & 0.65 \\
\hline
\end{tabular}

Table 4 explains that the shortest of nugget diameter is for C8T10F3. A welding time of $10 \mathrm{CT}$ and an electrode force of $32 \mathrm{~kg}$ produced a nugget diameter and thickness of $1.768 \mathrm{~mm}$ and 0.8 $\mathrm{mm}$, respectively. The nugget diameter of $3.427 \mathrm{~mm}$ for C8T6F52 is the longest nugget diameter, and the thickness is $0.72 \mathrm{~mm}$. The welding process using a welding time of $10 \mathrm{CT}$ and an electrode force of $32 \mathrm{~kg}$ produced a thickness of $0.8 \mathrm{~mm}$, which was the highest value of thickness. The thinnest nugget diameter is $0.56 \mathrm{~mm}$ for $\mathrm{C} 8 \mathrm{~T} 6 \mathrm{~F} 32$.

\section{CONCLUSION}

The RSW parameters significantly influence the mechanical properties, macrostructure, and microstructure of the weld joint. The effect of electrode force on maximum load and nugget size for a $0.4 \mathrm{~mm}$ thick plate of AA 1100 was studied, and the following found: (1) The result of the tensile shear test revealed that by increasing the electrode force, the load rate would be decreased; (2) The electrode force affects elongation. C8T8F32 and C8T8F52 have the longest elongation distances of more than $0.9 \mathrm{~mm}$ and more than $0.55 \mathrm{~mm}$, respectively. The trend for elongation distance is that it tends to decrease; however, with an electrode force of $52 \mathrm{~kg}$ it increased; (3) The highest values for diameter $(3.427 \mathrm{~mm})$ and thickness $(0.72 \mathrm{~mm})$ were achieved using a welding time of $6 \mathrm{CT}$ and an electrode force of $52 \mathrm{~kg}$. The weld nugget from a welding time of $10 \mathrm{CT}$ and an electrode force of $32 \mathrm{~kg}$ produced a weld nugget with $1.768 \mathrm{~mm}$ diameter and $0.8 \mathrm{~mm}$ thickness. This nugget diameter was the lowest, but the thickness value was the highest. The thinnest of the thicknesses was $0.56 \mathrm{~mm}$ and was achieved using a welding time of $6 \mathrm{CT}$ and an electrode force of $32 \mathrm{~kg}$. The effect of electrode force on the diameter and thickness of the weld nuggets in this study was not significant.

\section{ACKNOWLEDGEMENT}

The author would like to express his sincere gratitude for the financial support of Penelitian Unggulan Perguruan Tinggi (PUPT) RISTEK DIKTI 2017 from the Directorate of Research and Public Service, Universitas Indonesia, through the contract number: 2730/UN2.R3.1/HKP05.00/2017 with title of "Pengembangan Proses dan Evaluasi Kinerja Pengelasan Micro Resistance Spot dan Micro Stir Spot pada Konstruksi Ringan Logam yang Berbeda (Dissimilar Materials)". 


\section{REFERENCES}

Baskoro, A.S., Muzakki, H., Winarto, 2015. Influence of Time and Strong Current on Micro Resistance Spot Welding on Shear Stress and Thickness of Welded Area (Pengaruh Waktu dan Kuat Arus pada Pengelasan Micro Resistance Spot Welding Terhadap Tegangan Geser dan Tebal Daerah Lasan). In: Proceeding Seminar Nasional Tahunan Teknik Mesin XIV (SNTTM XIV)

Baskoro, A. S., Muzakki, H., Winarto, 2016. Effect of Welding Current and Welding Time for Micro Resistance Spot Welding on Dissimilar Thin Thickness Materials of Al 1100 and KS 5 Spring Steel. Applied Mechanics and Materials, Volume 842, pp. 120-124

Baskoro, A.S., Muzakki, H., Winarto, 2016. The Effect of Welding Time and Welding Currents on Weld Nugget and Tensile Properties of Thin Aluminum 1100 by Micro Resistance Spot Welding. ARPN Journal of Engineering and Applied Sciences, Volume 11, pp. 1050-1055

Bi, J., Song, J.L., Wei, Q., Zhang, Y., Yang, L., Luo, Z., 2016. Characteristics of shunting in resistance spot welding for dissimilar unequal-thickness aluminumalloys under large thickness ratio. Materials \& Design, Volume 101, pp. 226-235

Hernandez, V.H.B., Panda, S.K., Zhou, N.Y., Okita, Y., 2010. A Study on Heat Affected Zone Softening in Resistance Spot Welded Dual Phase Steel by Nanoindentation. J Mater Sci, Volume 45(6), pp. 1638-1647

Kianersi, D., Mostafaei, A., Amadeh, A.A., 2014. Resistance Spot Welding Joints of AISI 316L Austenitic Stainless Steel Sheets: Phase Transformations, Mechanical Properties and Microstructure Characterizations. Materials \& Design, Volume 61, pp. 251-263

Krajcarz, F., Lorenzon, A.-F.G., Lucas, E., Pineau, A., 2013. Fracture Toughness of the Molten Zone of Resistance Spot Welds. Int J Fract, Volume 181(2), pp. 209-226

Pal, T.K., Bhowmick, K., 2012. Resistance Spot Welding Characteristics and High Cycle Fatigue Behavior of DP 780 Steel Sheet. Journal of Materials Engineering and Performance, Volume 21(2), pp. 280-285

Papaefthymioua, S., Goulas, C., Gavalas, E., 2015. Micro-friction Stir Welding of Titan Zinc Sheets. Journal of Materials Processing Technology, Volume 216, pp. 133-139

Razmpoosh, M.H., Shamanian, M., Esmailzadeh, M., 2015. The Microstructural Evolution and Mechanical Properties of Resistance Spot Welded Fe-31Mn-3Al-3Si TWIP steel. Materials \& Design, Volume 67, pp. 571-576

$\mathrm{Xu}$, H., Xu, M.J., Yu, C., Lu, H., Wei, X., Chen, J.M., Xu, J.J., 2017. Effect of the Microstructure in Unmixed Zone on Corrosion Behavior of 439 tube/308L Tube-sheet Welding Joint. Journal of Materials Processing Technology, Volume 240, pp. 162-167

Zohoori-Shoar, V., Eslami, A., Karimzadeh, F., Abbasi-Baharanchi, M., 2017. Resistance Spot Welding of Ultrafine Grained/nanostructured Al 6061 Alloy Produced by Cryorolling Process and Evaluation of Weldment Properties. Journal of Manufacturing Processes, Volume 26, pp. 84-93 